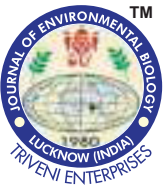

\title{
High-cell density cultivation of recombinant Pichia pastoris harboring fungal endoinulinase and prebiotics applications of inulo-oligosaccharides
}

\begin{tabular}{lll}
\hline Paper received: 27.03 .2018 & Revised received: 30.04 .2018 & Re-revised received: 12.05 .2018 \\
\hline
\end{tabular}

\begin{abstract}
Authors Info
M. Surendarbabu and S. Meenakshisundaram*

Centre for Biotechnology,

Anna University,

Chennai-600 025, India

*Corresponding Author Email : meenakshi@annauniv.edu
\end{abstract}

\section{Edited by}

Dr. Sumati Gaumat

Reviewed by

Dr. G. Baskar

Dr. R. B. Raizada

\section{Abstract}

Aim : The objective of the present study was to clone and express $A$. niger endoinulinase gene in $P$. pastoris for high-level expression. Further to explore high cell density cultivation, biochemical characterization of recombinant endoinulinase and application of inulo-oligosaccharides (IOS) as prebiotics was also studied.

Methodology : Molecular cloning of A. niger endoinulinase gene in P. pastoris, screening of positive clones by genomic DNAPCR, shake flask studies, high cell density fermentation performed with both conventional and temperature shift approach, biochemical characterization of endoinulinase and in-vitro fermentation of IOS was carried out to confirm prebiotic efficacy.

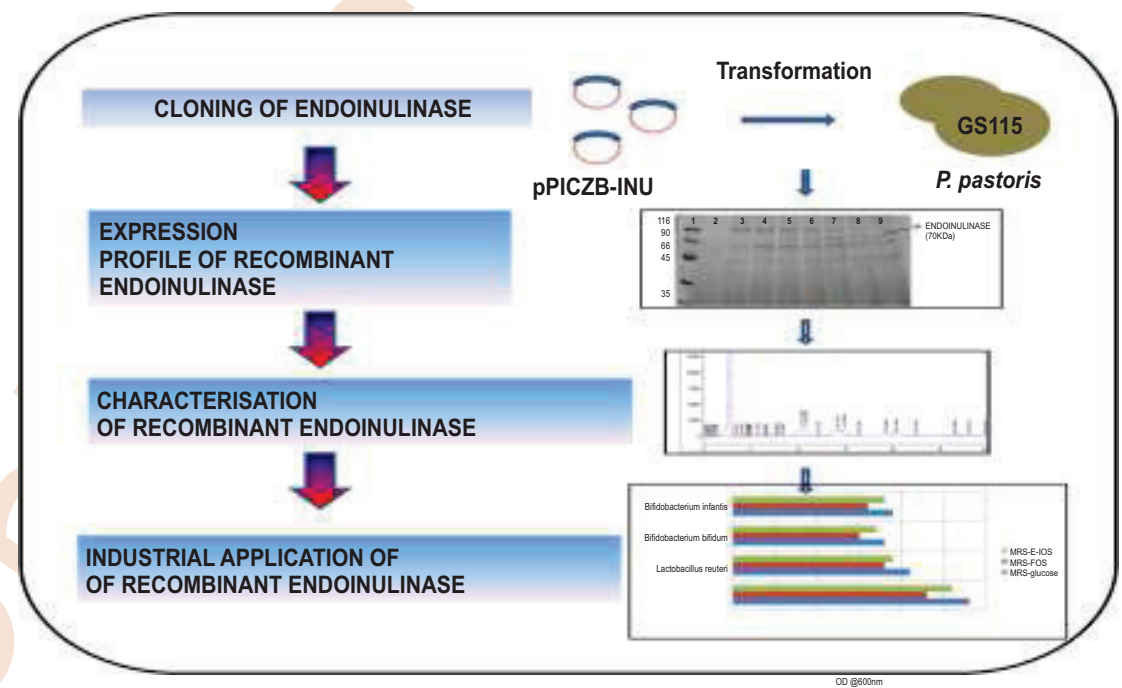

Results : The endoinulinase gene of $1482 \mathrm{bp}$ from Aspergillus niger was genetically engineered in the GS115 host and was secreted extracellularly using a signal sequence. As a result of fermentation with the conventional approach, recombinant endoinulinase activity was enhanced to $65.7 \mathrm{U} \mathrm{ml}^{-1}$. Recombinant endoinulinase showed absolute substrate specificity for inulin, hydrolyzing inulin to IOS with the DP range 3-4.

Interpretation : Hydrolysis of inulin by recombinant endoinulinase was characterized. In-vitro fermentation of IOS by lactic acid and bifidogenic bacteria was studied as a part of industrial application and functional properties of IOS was similar to commercial prebiotics.

Key words: Aspergillus niger, Endoinulinase, Inulin, Pichia pastoris, Prebiotics

How to cite: Surendarbabu, M. and S. Meenakshisundaram:High-cell density cultivation of recombinant Pichia pastoris harboring fungal endoinulinase and prebiotics applications of inulo-oligosaccharides. J.Environ. Biol. 40, 69-75 (2019). 


\section{Introduction}

Endoinulinase is a commercially important enzyme used for the fructo-oligosaccharides production. Endoinulinases hydrolyses inulin by endocleavage, producing inulooligosaccharides, whereas exoinulinase enzyme hydrolyses inulin by exoclevage to produces fructose as a major product. Prebiotics like fructo-oligosaccharides has an extensive range of applications ranging from aquaculture to food industries. The major problem in aquaculture nowadays is infectious diseases in fish as they create enormous loss. Prebiotic triggers innate immune response in fish, for example, it increases fish growth and also activates complement system (Carbone and Faggio, 2016). Fructo-oligosaccharides have greater functional properties as prebiotics, dietary fiber and Bifidus stimulating factor (Skowronek and Fiedurek, 2004). Oligosaccharides nowadays are broadly used as functional foods (Ladirat et al., 2014). Due to various application of oligosaccharides, demand for isomalto-oligosaccharides (Ojha et al., 2015), cellooligosaccharides (Chu et al., 2014), xylo-oligosaccharides (Moura et al., 2007), galacto-oligosaccharides (Ladirat et al., 2014), and fructo-oligosaccharides (FOS) (Gern et al., 2001; Ghazi et al., 2006) have improved rapidly. FOS is synthesized from inulin and sucrose by enzymatic hydrolysis (Nakamura et al., 1997) particularly, inulin derived FOS is mentioned as inulooligosaccharides (IOS). Lower Eukaryote yeast like P. pastoris is a significant host system for the expression of genes from heterologous sources (Cereghino and Cregg, 2000). Recombinant lipase expressed in different strains like Escherichia coli, S. cerevisiae and P. pastoris were compared to evaluate a better recombinant expression system. P. pastoris was evaluated as a potential host system for recombinant lipase production because of its better expression efficiency when compared with others recombinant strains (Valero, 2012).

Pichia pastoris has various advantages like it can easily grow in basal salt media, reach a very high cell density, and build up high concentrations of extracellular protein (Huang et al., 2003). In addition, P. pastoris, as an extensive expression system, can perform protein processing, folding, and post translational modifications. As endoinulinase has gained massive interest in both health and food industry, various microorganisms are used for the feasible production of endoinulinases such as Penicillium spp. (Nakamura et al., 1997), Arthrobacter spp. (Montesino et al., 1998), Aspergillus ficuum (Chen et al., 2012) and A. niger (Gern et al., 2001). A. niger ( DSM 2466) is one of the best producer for endoinulinase from isolated fungal strains which produces endoinulinase (Gern et al., 2001).

In this study, A. niger endoinulinase gene was cloned and expressed extracellularly in P. pastoris GS115. Fermentation was performed with both conventional and temperature shift approach to improve the recombinant enzyme expression level. In vitro fermentation of prebiotic inulo-oligosaccharides by lactic acid and bifidogenic bacterial strains was also studied to check the prebiotic efficacy of IOS produced.

\section{Materials and Methods}

Strains and culture media : A. niger/DSM 2466 was procured from German collection of microorganisms and cell cultures (DSMZ). E. coli DH5a (maintenance host), Pichia pastoris GS115 strain (expression host) and $p P I C Z a B$ (expression vector) were purchased from Invitrogen Co. Ltd. Restriction enzymes, DNA polymerases and T4 DNA ligase were purchased from Biolabs (New England Biolabs, USA). Fructo-oligosaccharide and Inulin were purchased from Sigma-Aldrich Co. Ltd. Plasmid extraction, PCR purification and gel elution kits were procured from Qiagen. All Medias used in this study were prepared according to the Invitrogen-Pichia Process Guidelines.

Construction of recombinant Plasmid : To obtain mature endoinulinase, 23 amino acids of the signal peptide (MLNPKVAYMVWMTCLGLTLPSQA) were removed. DNA sequence encoding the endoinulinase gene mature region without the predicted signal sequence was amplified by PCR using suitable sets of primers INU1 forward CGGAATTCCAGTCTAATGATTACCGTCC and INU1 reverseGAATGCGGCCGCTCATTCAAGTGAAACAC. After total RNA isolation from $A$. niger, cDNA was synthesized. The synthesized CDNA was used as a template for PCR reactions. Recombinant plasmids pPICZB-INU1 was constructed using PCR amplified INU1 gene from A. niger.

Transformation of constructed vector in Pichia pastoris : The linearized pPICZaB-INU1 plasmid construct of $10 \mu \mathrm{g}$ was mixed with $80 \mu$ competent cells in electroporation cuvette $(0.2 \mathrm{~cm})$ and pulsed (1500 V, $250 \Omega, 50 \mu \mathrm{F})$ using ECM@630 electroporator (BTX, San Diego, CA, USA) as per Invitrogen manual. Post electroporation, the positive transformants were screened using Zeocin antibiotic resistance in Yeast Peptone Dextrose agar medium. To further confirm the positive transformants, genomic DNA of resistant colonies was isolated and checked for the presence of plasmid construct by PCR using gene-specific primers.

Expression analysis in shake flask cultivations : Expression study of recombinant $P$. pastoris strains was performed in shake flask. Once the cells reached mid-log phase, cells were harvested from a $50 \mathrm{ml}$ flask, centrifuged and transferred to $15 \mathrm{ml}$ expression medium (Basal methanol medium). Induction was performed with methanol concentration of $1 \%(\mathrm{v} / \mathrm{v})$ for $120 \mathrm{hrs}$ at an interval of 24 hrs. The recombinant endoinulinase expression was analyzed by endoinulinase enzyme assay (Chen et al., 2009) and the amount of protein expressed after induction was detected by SDS PAGE.

Bioreactor cultivation : Fermentation studies were carried out using a Basal Salt Medium supplemented with glycerol as major carbon source during growth phase and induction of AOX gene which is present upstream to gene sequence was triggered by methanol for the production of endoinulinase enzyme. A 3.7 I bioreactor (KLF2000, Bioengineering AG, Switzerland) with initial working volume of 2 I was equipped with online $\mathrm{pH}$ and $\mathrm{DO}$ control module. The key bioprocess parameters maintained during 
fermentation included agitation (300-500 rpm), pH (setpoint 4.8) was adjusted with $28 \% \mathrm{NH}_{4} \mathrm{OH}$ and $50 \% \mathrm{H}_{3} \mathrm{PO}_{4}$ and temperature $\left(28^{\circ} \mathrm{C}\right)$. Polypropylene glycol was used as antifoam to prevent excessive foaming.

Assay of endoinulinase, SDS PAGE and PAS staining : The reaction mixture of $600 \mu \mathrm{l}$ of $5 \%(\mathrm{w} / \mathrm{v})$ inulin dissolved in $50 \mathrm{mM}$ sodium acetate buffer ( $\mathrm{pH} 6.0$ ), $10 \mu \mathrm{l}$ of $0.5 \mathrm{M} \mathrm{CaCl}_{2}$, and $150 \mu \mathrm{l}$ of appropriately diluted enzyme. The reaction was then incubated at $55^{\circ} \mathrm{C}$ for $10 \mathrm{~min}$ and ended by incubating the reaction mixture in boiling water for $5 \mathrm{~min}$. The amount of reducing sugar liberated was determined using DNS method, where absorbance was measured at $520 \mathrm{~nm}$ (Miller, 1959). Endoinulinase activity was directly proportional to $\mu \mathrm{mol}$ of reducing sugar liberated per minute under the assay conditions (Chen et al., 2009). SDSPAGE was performed on a $12 \%$ polyacrylamide gel and the gel was developed with $0.25 \%$ Coomassie Brilliant Blue R-250. For the detection of glycosylation by PAS staining, the protein was separated on $12 \%$ SDS-PAGE gel, the glycoprotein was oxidized with $1 \%$ periodic acid for one hour. The protein band was stained with Schiff's reagent and incubated in dark. The reaction was finally terminated with $0.1 \%$ sodium metabisulfide solution.

Characterization of recombinant endoinulinase : The relative activity was determined at diverse $\mathrm{pH}$ values ranging from 4.0 to 8.0 at $60^{\circ} \mathrm{C}$. To estimate $\mathrm{pH}$ stability, samples were incubated at $60^{\circ} \mathrm{C}$ for $1 \mathrm{hr}$ with respective $\mathrm{pH}$ buffers and checked for residual activity. The optimal temperature of recombinant endoinulinase was checked by analyzing the enzyme activity at diverse temperatures $30-80^{\circ} \mathrm{C}$ in sodium acetate buffer, $\mathrm{pH}$ 6.0. The stability of enzyme with respect to temperature was intended by incubating endoinulinase at varied temperatures up to $1 \mathrm{hr}$ at $\mathrm{pH}$ 6.0. The $K_{m}$ and $V_{\text {max }}$ values were calculated using line weaverBurk plot.

TLC and HPLC analysis : Thin-layer chromatography (TLC) was carried out for the hydrolysed product on silica gel 60 TLC plate. The solvent system of $n$-butanol-ethanol-water (5:3:2 v/v/v) was used for the capillary movement and the sugar spots were developed with $5 \%$ sulfuric acid in methanol and the plate was

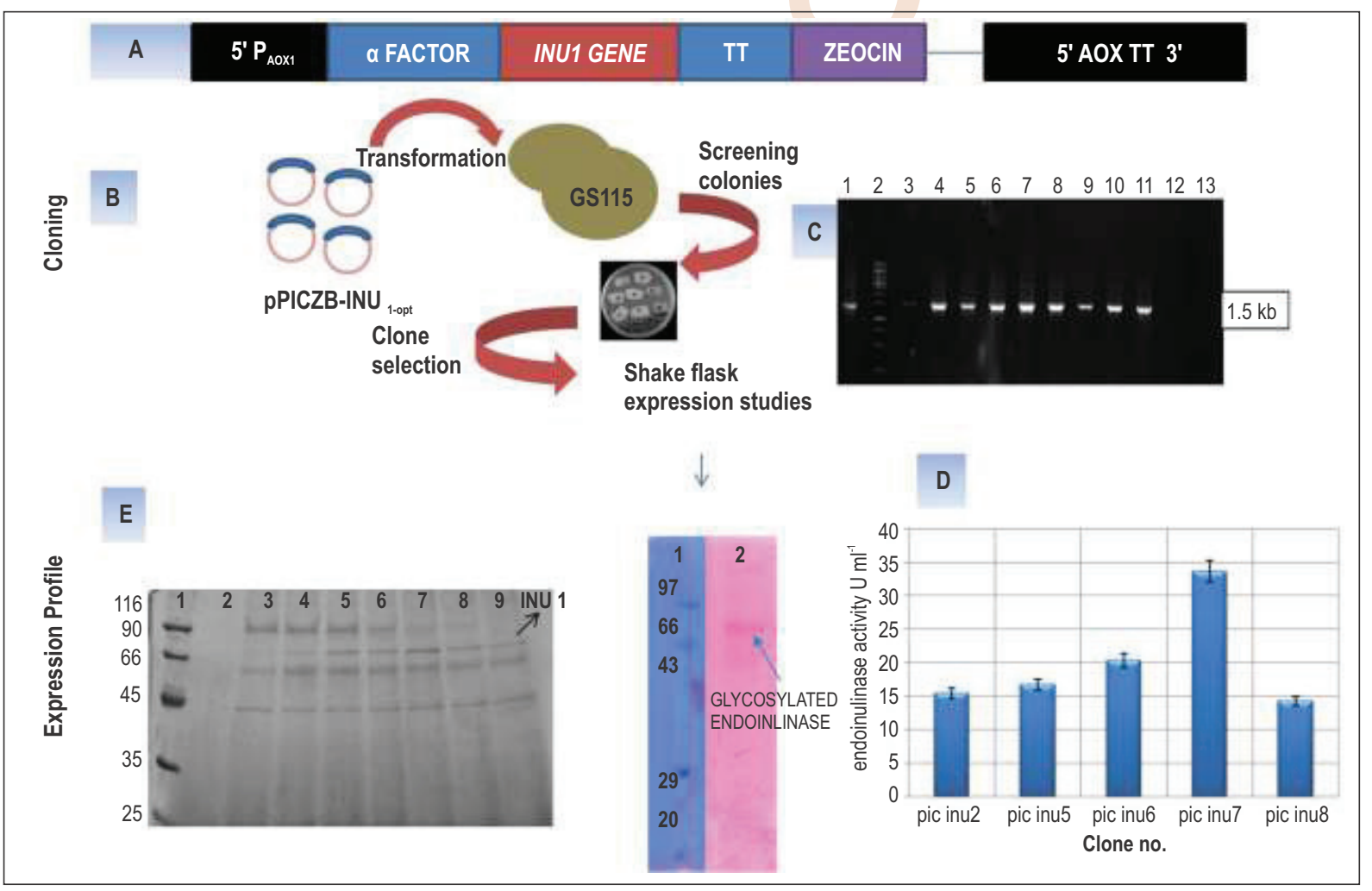

Fig. 1: (A) Schematic representation of recombinant plasmid expression cassette; (B) Schematic diagram for cloning and expression of $A$. niger endoinulinase in Pichia pastoris; (C) Genomic DNA PCR analysis. Lane 1 pPICZaB-INU1 plasmid PCR product as a positive control. Lane 2 DNA $1 \mathrm{~kb}$ marker. Lane 3-11. PCR product of positive recombinant transformants. Lane 12. Negative control (only plasmid); (D) Shake flask expression profile of positive clones; (E) SDS-PAGE examination of recombinant endoinulinase expressed. Lane 1. Protein molecular marker. Lane 2, uninduced culture supernatant Lane 3-9, culture supernatant of recombinant Pichia pastoris GS115- after induction by methanol every 24 hrs. Protein band with approximately $70 \mathrm{kDa}$ molecular weight was evidently apparent on the SDS-PAGE. PAS staining of recombinant endoinulinase, Lane1. Protein molecular weight marker Lane 2. PAS staining for glycosylated recombinant endoinlinase. 
kept at $100^{\circ} \mathrm{C}$ for $3 \mathrm{~min}$ (Bernardi et al., 2015). HPLC analysis was performed for the product of inulin hydrolysis by using a Shodex Asahipak NH2P-50 4E column $(4.6 \times 250 \mathrm{~mm}$, Shodex Separation \& HPLC Group, Japan) and an RI (refractive index) detector. The elution buffer contained the mixture of $75 \%$ acetonitrile and $25 \%$ water, and the flow rate was of $0.6 \mathrm{ml} \mathrm{min}^{-1}$ was maintained at $25^{\circ} \mathrm{C}$.

In-vitro fermentation of IOS by lactic acid and bifidogenic bacteria : To confirm growth was dependent on IOS utilization, lactic acid and bifidogenic bacterial strains were inoculated into $10 \mathrm{ml}$ MRS basal broth containing $2 \%$ glucose (positive control), $2 \%$ commercial FOS and $2 \%$ IOS (recombinant-endoinulinase hydrolsed) as carbohydrate source in a $25 \mathrm{ml}$ flask for $24 \mathrm{hrs}$ at $37^{\circ} \mathrm{C}$ and $200 \mathrm{rpm}$. (modified the protocol as per Rossi et al., 2005) The final cell density of probiotic bacteria for utilization of prebiotics was measured by Optical density at $600 \mathrm{~nm}$ after $24 \mathrm{hrs}$.

\section{Results and Discussion}

The constructed expression vector $p P I C Z a B-I N U 1$ shown in the schematic diagram (Fig. 1B), harbors the 1482-bp (comprises 494 amino acid) INU1 gene sequence in frame with the alpha-factor pre-pro secretion signal between the AOX1 promoter and $A O X 1$ transcriptional terminator shown in Fig $1 \mathrm{~A}$. The pre-pro-sequence of $\mathrm{S}$. cerevisiae provides extracellular secretion of several heterologous expressed proteins in $P$. pastoris (Ghazi et al., 2006; Yun et al., 1997). The positive transformants were confirmed, by genomic DNA PCR using gene-specific forward and reverse primers. Integration of recombinant plasmid construct in Pichia genome was confirmed by the presence of $1.5 \mathrm{~kb}$ band in $1 \%$ agarose gel electrophoresis (Fig. 1C) and positive clones identified through genomic DNA PCR were selected for shake flask studies. The gene homology examination was carried out by comparing A. niger (DSM 2466) with $A$. ficuum JNSP5-06, A. niger CBS513.88 and A. niger 9891 that resulted in more than $96 \%$ endoinulinase gene similarity.

The extracellular expression of endoinulinase by positive transformants was studied in expression media containing methanol, which was used for the overexpression of endoinulinase gene through induction of AOX promoter sequence. The level of recombinant protein expression was enhanced by well controlled and powerful AOX promoter operated by methanol (Vogl and Glieder, 2013). The recombinant endoinulinase expressed successfully into the expression media and maximum endoinulinase activity observed after 5 days in shake flask level was $33 \mathrm{U} \mathrm{ml}^{-1}$ (Fig.1D), which was 2 fold higher when compared to endoinulinase expression by wild-type $A$. niger. SDS-PAGE analysis showed a band of monomeric glycoprotein with a molecular size range of $70 \mathrm{kDa}$ (Fig.1 E).

The heterologous protein expression in $P$. pastoris underwent post-translation glycosylation modification as per the glycosylation machinery of eukaryote, additional carbohydrate moieties were attached to the core protein and also varies among the amino acid sequence of interest (Moura et al., 2007). The molecular weight of endoinulinase was increased because of the addition of carbohydrate moieties in the potential glycosylation sites present in the gene sequence. To determine the

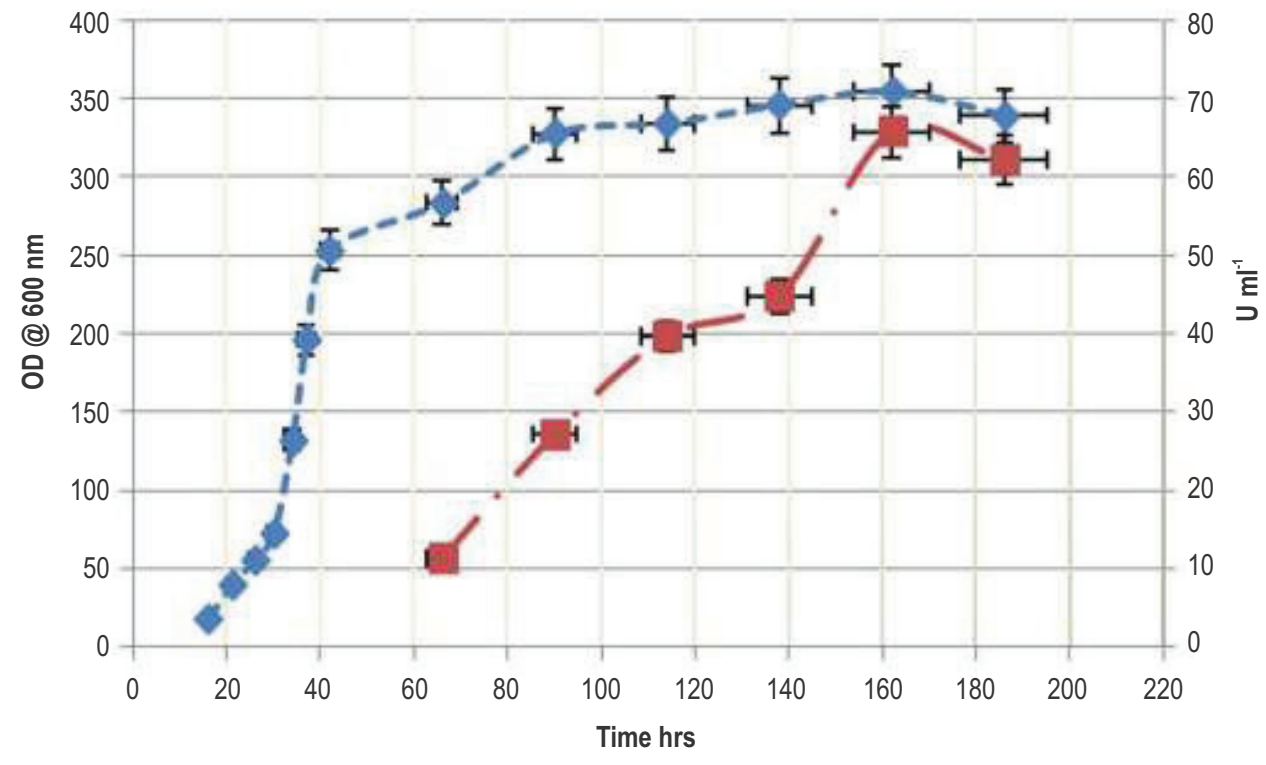

Fig. 2 : Fermentation profile of recombinant endoinulinase produced through conventional approach at $28^{\circ} \mathrm{C}$. The conventional approach fed-batch cultivation which was normally carried out at $28^{\circ} \mathrm{C}$ resulted in maximum endoinulinase expression of $65.7 \mathrm{U} \mathrm{ml}^{-1}$. The data are mean $\pm \mathrm{SD}$ of three

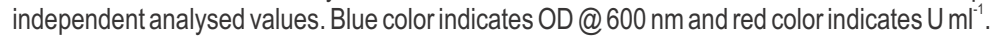


accumulation of carbohydrate moieties linked with recombinant endoinulinase, PAS staining was performed to confirm the glycosylation of protein as shown in Fig.1E. Overall molecular weight of recombinant endoinulinase was approximately $70 \mathrm{kDa}$, in that approximately $30-35 \%$ was contributed by the carbohydrate attachments. To increase the recombinant endoinulinase expression significantly, fed batch cultivation with the conventional and temperature limitation approaches were explored. Aspergillus fumigates endoinulinase gene was overexpressed in Pichia spp. and successfully produced the enzyme as a result of conventional fermentation process (Chen et al., 2015).

In the current study, the conventional approach fed-batch cultivation which was normally carried out at $28^{\circ} \mathrm{C}$, resulted in maximum endoinulinase expression of $65.7 \mathrm{U} \mathrm{ml}^{-1}$ (Fig. 2) and to further improve the expression of recombinant endoinulinase temperature limitation approach at $20^{\circ} \mathrm{C}$ during induction phase was studied and resulted in $82.5 \mathrm{U} \mathrm{ml}^{-1}$ after $120 \mathrm{hrs}$ of induction phase (data not shown). The shift to a lower temperature during methanol induction decreased the dead cell count and resulted in less proteolysis which was directly correlated to an enhanced expression profile of recombinant proteins (Jahic et al., 2003). In the current study shift to a temperature significantly enhanced the productivity of endoinulinase compared to conventional approach. The endoinulinase gene isolated from wild-type Arthrobacter spp. S37 strain was engineered and expressed in Yarrowia spp. The maximum activity reported by positive recombinant clone was $16.7 \mathrm{U} \mathrm{ml}^{-1}$ (Montesino et al., 1998). A. niger 9819 endoinulinase gene was cloned and overexpressed intracellularly in P. pastoris GS115 (Wang et al., 2004). But in this study, the endoinulinase was actively secreted extracellularly which reduced the need for further purification steps. The wildtype $A$. niger strain used in this work was found to overexpress endoinulinase when compared to different endoinulinase producing fungal strains and it was found that the strain produced only endoinulinase (Gern et al., 2001). In the current study, the specific isolation of endoinulinase gene was performed, whereas many Aspergillus strains produce both endoinulinase and exoinulinase which made isolation of specific gene of interest difficult.

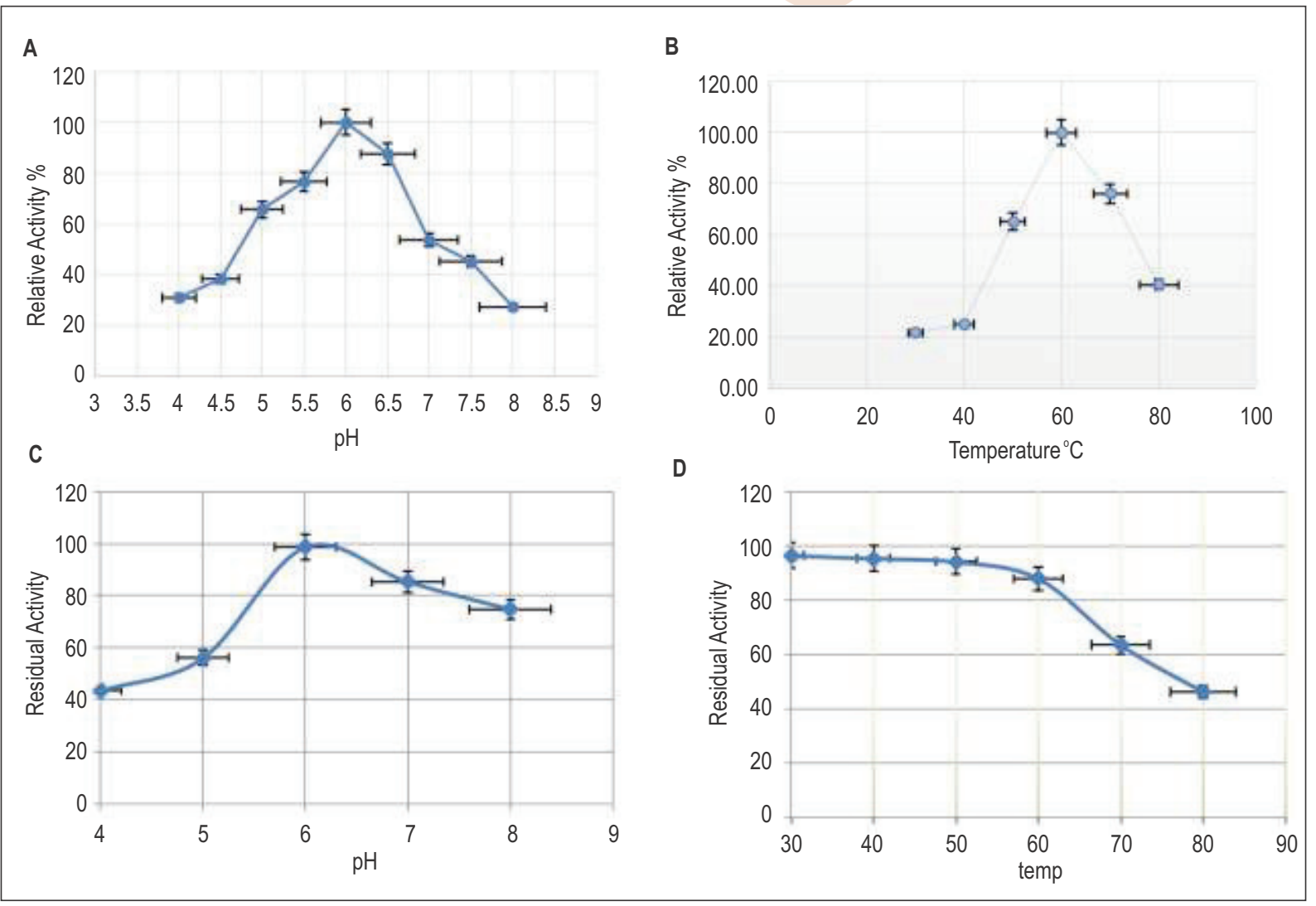

Fig. 3 : (A) The optimum pH for endoinulinase activity was pH 6.0; (B) The optimum temperature for endoinulinase activity was studied, the optimal temperature to obtain maximum activity was $60^{\circ} \mathrm{C}$; (C) The stability of $\mathrm{pH}$ was measured and shown to have stability in varied pH range; (D) The stability was analysed by incubating recombinantendoinulinase, the enzyme retained about $85 \%$ of the activity at $60^{\circ} \mathrm{C}$. Values are mean of three replicates $\pm S D$. 


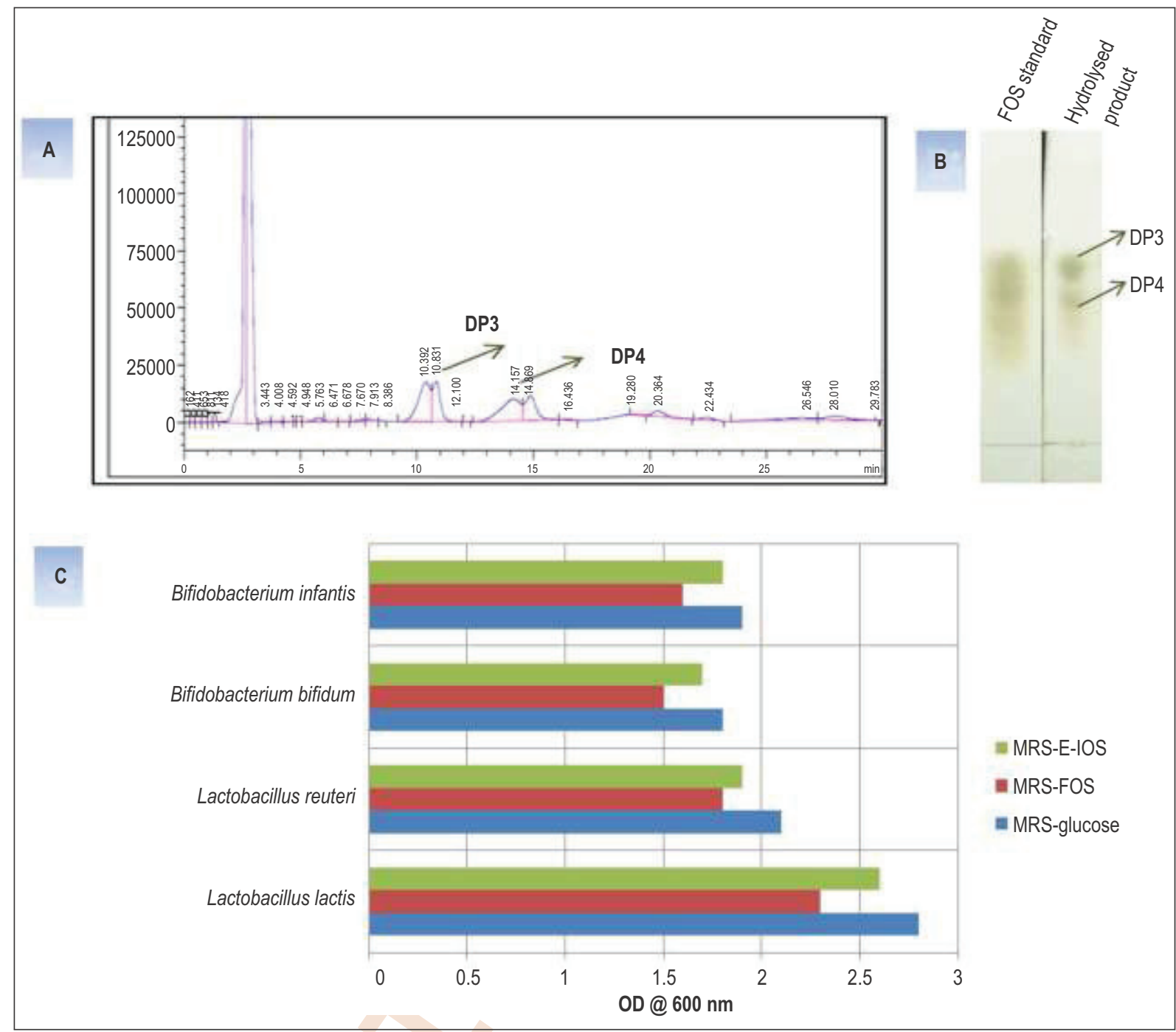

Fig. 4 : (A). HPLC profile for inulin hydrolysis by recombinant endoinulinase. Analysis shows peaks for Inulotriose (DP3) with retention time of 12 mins, inulotetraose (DP4) with retention time of 14 mins; (B) TLC profile for inulin hydrolysis by recombinant endoinulinase; (C) IOS which is obtained by hydrolyzing inulin by recombinant endoinulinase enzyme show prebiotic efficacy in supporting the growth of Bifidobacterium and lactic acid bacteria. Probiotic microorganism growth in presence of MRS-IOS comparatively similar with growth in MRS supplemented with glucose and commercial FOS.

The optimum $\mathrm{pH}$ for endoinulinase activity was studied, more than $80 \%$ residual activity of the enzyme was retained at $\mathrm{pH}$ 6.0 (Fig 3A). The pH stability was measured by analyzing the remaining enzyme activity after incubating recombinant endoinulinase at various $\mathrm{pH}$ for $1 \mathrm{hr}$ at $60^{\circ} \mathrm{C}$. It was stable over a $\mathrm{pH}$ choice of $4.0-8.0$, retaining its initial activity over $40 \%$ at acidic $\mathrm{pH}$ and $98 \%$ at optimum $6.0 \mathrm{pH}$ (Fig. 3B). Optimum $\mathrm{pH}$ for yeast strains producing endoinulinases was found to be 4.4 to 6.5 (Rastall, 2010). The optimal temperature for endoinulinase activity was studied by incubating the recombinant enzyme in a temperature ranged from $30-80^{\circ} \mathrm{C}$ at $\mathrm{pH} 6.0$ and the optimal temperature to obtain maximum activity was $60^{\circ} \mathrm{C}$ (Fig. $3 \mathrm{C}$ ). The temperature stability was analyzed by incubating endoinulinase at different temperatures and the enzyme retained about $85 \%$ of the activity at $60^{\circ} \mathrm{C} \mathrm{(Fig.} \mathrm{3D).} \mathrm{K}_{\mathrm{m}}$ of recombinant endoinulinase was found to be $20 \mathrm{mM}$ while its $\mathrm{V}_{\max }$ was $111 \mathrm{U} \mathrm{I}^{-1} \mathrm{~min}^{-1}$. The recombinant enzyme showed absolute specificity towards inulin substrate and produced inulotriose (DP3) and inulotetrose (DP4) as hydrolyzed product which was shown in thin layer chromatography (Fig. 4B) and the peaks for DP3 and DP4 was evident in HPLC analysis (Fig. 4A). Long-chain fructans (DP range greater than 9) was formed by using inulin as a substrate, while short-chain fructans were produced (DP lesser than 4 ) by using sucrose as substrate (Roberfroid et al., 1998). The recombinant endoinulinase showed sucrose hydrolysis pattern, with $\mathrm{DP}$ range $(\mathrm{DP}<4)$ for inulin hydrolyzed product, however the 
hydrolyzed product showed similarity with commercial prebiotics like GOS $(\mathrm{DP}=2-4)$ and NutraFlora ${ }^{\mathrm{P}} \mathrm{P}-95(\mathrm{DP}=2-4)$.

IOS which was obtained by hydrolyzing inulin by recombinant endoinulinase enzyme showed prebiotic efficacy in supporting the growth of Bifidobacterium and lactic acid bacteria (Fig. 4C). Growth rates of probiotic bacteria utilizing IOS, as a carbon source, were similar to growth observed when using glucose and commercial FOS as a carbon source. These results recommended that IOS utilization did not require an induction period and that IOS was an equally good substrate as glucose in sustaining the growth of probiotics. The short chain IOS derived as an end result of the current study can be used as potential prebiotics, since nearly all probiotic bacteria ferment shortchain FOSs for their growth promotion (Rossi et al., 2005)

The endoinulinase gene of $1482 \mathrm{bp}$ from Aspergillus niger was genetically engineered in the GS115 host and was secreted extracellularly using a signal sequence. The recombinant endoinulinase produced was further characterized. The IOS produced using recombinant endoinulinase from Pichia pastoris showed sustained growth of probiotics. The prebiotics produced after hydrolysis by recombinant endoinulinase can be used in aquaculture and food industries.

\section{Acknowledgment}

The authors are thankful to CSIR for providing the research fellowship. The authors declare no conflict of interest.

\section{References}

Bernardi, T. P. Pedrini, M.G. Marchetti and E. Tamburini: Separation and quantitative determination of carbohydrates in microbial submerged cultures using different planar chromatography techniques (HPTLC, AMD, OPLC). J. Anal. Bioanal. Tech., 6, 250 (2015).

Cereghino, J.L. and J.M. Cregg : Heterologous protein expression in the methylotrophic yeast Pichia pastoris. FEMS Microbiol. Revi., 24, 45-66 (2000).

Carbone, D. and C. Faggio: Importance of prebiotics in aquaculture as immunostimulants. Effects on immune system of Sparus aurata and Dicentrarchus labrax. Fish Shellfish Immunology, 54,172-8 (2016).

Chen, X.M., X.M. Xu, Z.Y. Jin and H.Q. Chen: Expression of an endoinulinase from Aspergillus ficuum JNSP5-06 in Escherichia coli and its characterization. Carbohydrate Polymers, 88, 748-753 (2012).

Chu, Q., X. Li, Y. Xu, Z. Wang, J. Huang, S. Yu and Q. Yong: Functional cello-oligosaccharides production from the corncob residues of xylo-oligosaccharides manufacture. Process Biochem., 49, 12171222 (2014).

Chen, H.Q., X.M. Chen, Y. Li, J. Wang, Z.Y. Jin, X.M. Xu, J.W. Zhao, T.X. Chen and Z.J. Xie: Purification and characterisation of exo-and endo-inulinase from Aspergillus ficuum JNSP5-06. Food Chem., 115, 1206-1212 (2009).

Chen, M., X. Lei, C. Chen, S. Zhang, J. Xie and D. Wei: Cloning, overexpression and characterization of a highly active endoinulinase gene from Aspergillus fumigatus $\mathrm{Cl} 1$ for production inulooligosaccharides. Appl. Biochem. Biotechnol., 175, 1153-67(2015).
Gern, R.M., S.A. Furlan, J.L. Ninow and R. Jonas: Screening for microorganisms that produce only endo-inulinase. Appl. Microbiol. Biotechnol., 55, 632-635 (2001).

Ghazi, I., L. Fernandez-Arrojo, A. Gomez De Segura, M. Alcalde, F.J. Plou and A. Ballesteros: Beet sugar syrup and molasses as lowcost feedstock for the enzymatic production of fructooligosaccharides. J. Agricul. Food Chemi., 54, 2964-2968 (2006).

Huang, W.C., A.Y. Wang, L.T. Wang and H.Y. Sung: Expression and characterization of sweet potato invertase in Pichia pastoris. J. Agricul. Food Chemi., 51,1494-1499 (2003).

Ladirat, S.E., F.H.Schuren, M.H. Schoterman, A. Nauta, H. Gruppen and H.A. Schols: Impact of galacto-oligosaccharides on the gut microbiota composition and metabo GFc activity upon antibiotic treatment during in vitro fermentation. FEMS Microbiol. Ecol., 87, 41-51 (2014).

Li, Y., G.L. Liu, K. Wang, Z.M. Chi and C. Madzak: Overexpression of the endo-inulinase gene from Arthrobacter sp. S37 in Yarrowia lipolytica and characterization of the recombinant endo-inulinase. J. Molecular Catalysis B. Enzymatic, 74, 109-115 (2012).

Montesino, R., R. Garcla, O. Quintero and J.A. Cremata: Variation in Nlinked oligosaccharide structures on heterologous proteins secreted by the methylotrophic yeast Pichia pastoris. Protein Expres. Purifica., 14, 197-207(1998).

Moura, P., R. Barata, F. Carvalheiro, F. Gírio, M.C. Loureiro-Dias and M.P. Esteves: In vitro fermentation of xylo-oligosaccharides from corn cobs autohydrolysis by Bifido bacterium and Lactobacillus strains. LWT-Food Sci. Technol., 40, 963-972 (2007).

Miller, G. L.: Use of dinitrosalicylic acid reagent for determination of reducing sugar. Anal. Chem., 31, 426-428 (1959).

Jahic, M., W. Fredrik, B. Monika, G. Percival and E. Sven-Olof: Temperature limited fed-batch technique for control of proteolysis in Pichia pastoris bioreactor cultures. Microb. Cell Fact., 2, 6 (2003).

Rossi, M., C. Claudio, A. Alberto, N. Marcello, P. Anna, Z. Simona and M. Diego: Fermentation of fructooligosaccharides and inulin by bifidobacteria: A comparative study of pure and fecal cultures. Applied Environ. Microbio., 71, 6150-6158 (2005).

Nakamura, T., A. Shitara, S. Matsuda, T. Matsuo, M. Suiko and K. Ohta: Production, purification and properties of an endoinulinase of Penicillium sp. TN-88 that liberates inulotriose. J. Fermen. Bioengine., 84, 313-318 (1997).

Ojha, S., S. Mishra and S. Chand: Production of isomaltooligosaccharides by cell bound a-glucosidase of Microbacterium sp. LWT-Food Sci. Technol., 60, 486-494 (2015).

Rastall, R.: Functional oligosaccharides: application and manufacture. Annual Revi. food Sci. Technol., 1, 305-339 (2010).

Roberfroid, M.B., J.A. Van Loo and G.R. Gibson: The bifidogenic nature of chicory inulin and its hydrolysis products. The J. Nutrit., 128, 1119 (1998).

Skowronek, M. and J. Fiedurek: Optimisation of inulinase production by Aspergillus niger strain using simplex and classical method. Food Technolo. Biotechnol., 42, 141-146 (2004).

Valero, F.: Heterologous expression systems for lipases: A review. Methods Mol. Biol., 861, 161-178 (2012).

Vogl, T. and A. Glieder: Regulation of Pichia pastoris promoters and its consequences for protein production. New Biotechnol., 30, 385404 (2013).

Wang, J.H., D. Teng, Y. Yao, Y.L. Yang and F. Zhang: Expression of Aspergillus niger 9891 endoinulinase in Pichia pastoris. High Technol. Lett., 10, 52-56 (2004).

Yun, J.W., D.H. Kim, B.W. Kim and S.K. Song: Production of inulooligosaccharides from inulin by immobilized endoinulinase from Pseudomonas sp. J. Fermentat. Bioengine., 84, 369-371(1997). 